\title{
Метастатичний тричі негативний рак молочної залози: глухий кут чи перманентний стиму^ наукового пошуку в кАінічній онкології? (Наукове есе)
}

\begin{abstract}
Резюме. Рак молочної залози залишається одним із найпоширеніших у світі злоякісних новоутворень у жінок як у розвинутих країнах, так і в країнах, що розвиваються. Згідно з даними Globocan у 2020 році, кількість випадків захворювання на рак молочної залози становить 11,7 \% від усіх випадків діагностування онкозахворювань. В Україні найвищий показник захворюваності (27,6 \%) та смертності (25,5\%) від раку молочної залози серед жінок припадає на вік 30-54 роки, тобто на найбільш соціально активний період життя. Метастатичний рак молочної залози є узагальненим терміном для широкої групи захворювань зі спільним механізмом виникнення, але з вираженим різноманіттям у гістології, біології та клінічній картині. Сучасне лікування гормонпозитивного раку та HER2/nеи-позитивного субтипу призводить до тривалого контролю над хворобою та значного покращення показників безрецидивної та загальної виживаності. Проте 10-15\% становить тричі негативний субтип, що традиційно характеризується агресивним перебігом, несприятливим прогнозом та дефіцитом мішеней для таргетної терапії. Отже, актуальним питанням лишається пошук нових мішеней, які можлливо оцінити, та їх практичне застосування у лікуванні раку молочної залози.
\end{abstract}

Ключові слова: рак молочної залози; гормононегативний рак; лікування

\section{Вступ}

Постійні молекулярно-генетичні дослідження, зростаюче в геометричній прогресії поле терапевтичних можливостей, спроба проникнути в суть хвороби та осягнути іiї таємниці, а можливо, й зухвала мрія покласти їй край - усе це так приваблює і захоплює нас у цій вічно мінливій спеціальності. Наші дні сповнені науковою гонитвою, довгими мандрівками у нетрі медицини, політики, літератури, культури та історії зі скромним задумом зробити свій внесок та хоча б на крок наблизитися до тих яскравих особистостей, що протягом поколінь вступали в цю битву.

Йтиметься про метастатичний рак молочної залози (РМ3). Сьогодні це гетерогенне захворювання з вираженим гістопатологічним та геномним розмаїттям та невтішним прогнозом. Незважаючи на зусилля зануритися у фундаментальні наукові дослідження, більшість наших уявлень про персоніфіковане лікування раку є теоретичними. Отже, цей огляд підсумовує інформацію про гетерогенність пухлин, наявні біомаркери, які необхідно брати до уваги під час лікування поширеного раку молочної залози, та перспективи їх застосування в практичній медицині.

Уперше ідея про те, що рак молочної залози - неоднорідна нозологія, яка включає декілька підтипів, була висловлена у роботі С.M. Perou та співавторів, опублікованій у журналі Nature у 2000 р. У ній було ідентифіковано 5 підтипів раку молочної залози: люмінальний A, люмінальний B (HER-негативний), люмінальний B (HER2-позитивний), HER2-позитивний нелюмінальний, тричі негативний (ТНРМЗ) (рис. 1). Кожний із підтипів мав свої специфічні біологічні характеристики, проте самі автори наголошували на тому, що ми ще далекі від розуміння повної картини різноманітності пухлин і зв'язку цих знань із клінічною практикою через високу вартість методу NGS (геномне секвенування нового покоління). Проте з удосконаленням лабораторних методик визначення сурогатних маркерів, а саме значним поширенням ідентифікації білків методом імуногістохімії (IГX), а не генів (NGS), менше

\footnotetext{
(C) «Практична онкологія» / «Practical oncology» («Praktična onkologiâ»), 2021
}

(с) Видавець Заславський 0.10. / Publisher Zaslavsky 0.Yu., 2021

Для кореспонденції: Гловацька К.Д., Національний медичний університет імені 0.0. Богомольця, бульв. Т. Шевченка, 13, м. Київ, 02000, Україна; е-mail: redact@i.ua For correspondence: K. Hlovatska, Bogomolets National Medical University, T. Shevchenko boulevard, 13, Kyiv, 02000, Ukraine; e-mail: redact@i.ua 
ніж за 10 років процедура ІГХ-дослідження та виділення підтипів раку молочної залози надійно затвердилась у стандартах лікування цих пухлин. За статистикою, $78 \%$ випадків належать до гормонпозитивного раку, проте 10-15\% становить тричі негативний субтип, що традиційно характеризується резистентністю до терапії та раннім метастазуванням. Особливо несприятливим прогнозом характеризується метастатичний ТНРМЗ, за якого медіана виживаності не перевищує 13,3 місяця.

Рецептори естрогену (ER), рецептор прогестерону (PR) і рецептори епідермального фактора росту людини 2 (HER2) мають предиктивне та прогностичне значення.

У журналі Annals of Oncology в 2018 р. було опубліковано дослідження Dr. Curigliano, у якому було порівняно подібність між первинним та метастатичним раком молочної залози під час повторної біопсії вогнища у печінці. За даними авторів, 14 \% пухлин змінили статус ER, 49 \% мали розбіжність у статусі PR, а $14 \%$ мали зміни в статусі HER2 [1].

Повторна біопсія клінічно підозрілих уражень може гістологічно підтвердити наявність метастазів, оцінити розбіжності між ER, PR та статусом HER2 та виключити вторинне злоякісне новоутворення, яке може змінити терапевтичну стратегію для пацієнтів з раком молочної залози. Невідповідність ER, PR i HER2 призводить до зміни лікування у $30 \%$ випадків.

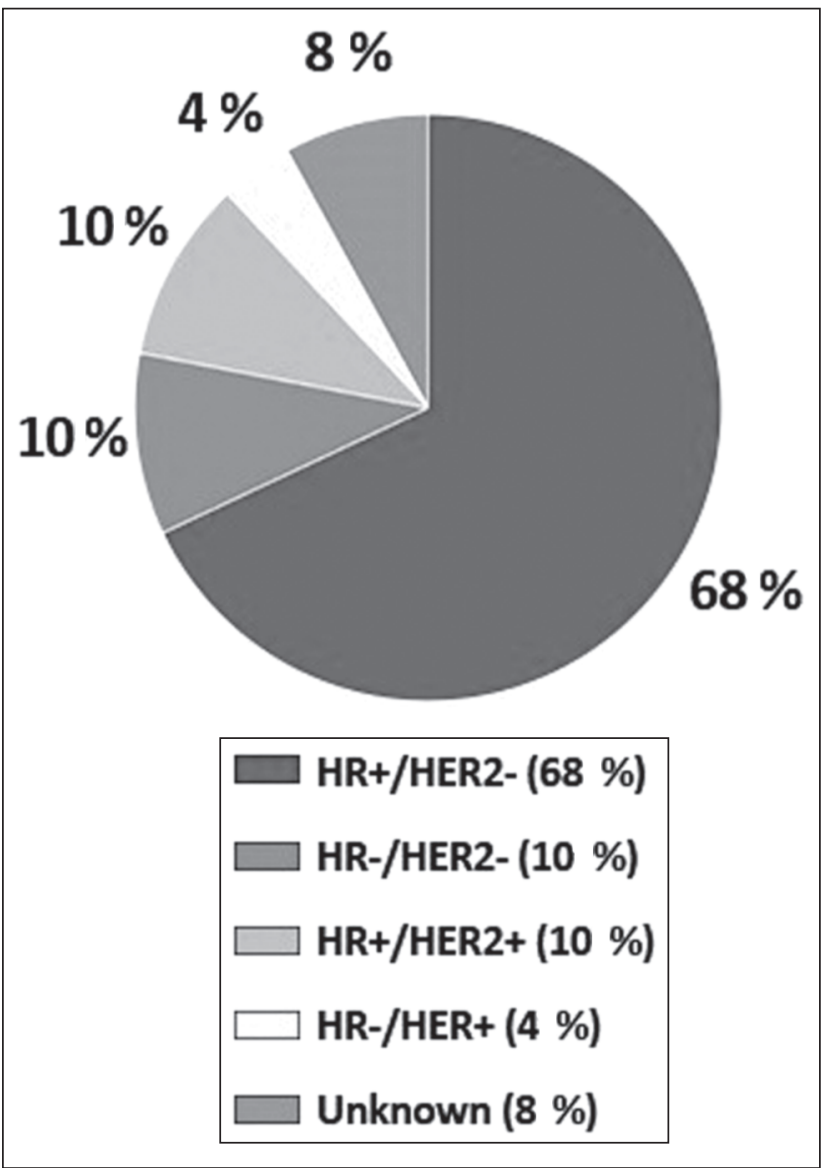

Рисунок 1. Поширеність фенотипів раку молочної залози в популяції (цит. за: https://oncologynursece.com/her2-negative-breast-cancer-epidemiology/)

\section{І. Коли чорне сКлаАно виАати за біле, його спочатку виАають за сіре}

Цікаво, що всі випадки з експресією білка HER2/ neu 1+ або 2+ за даними імуногістохімії, але без виявлення ампліфікації гена Her2 (FISH-негативні) мають назву «low HER пухлини» та $є$ клінічно цікавими. Відомо, що пацієнтки без ампліфікації гена HER2/neu не отримують переваги від звичайної анти-HER2-терапії, а зокрема від застосування трастузумабу та пертузумабу. Проте тривають дослідження кон'югату моноклонального антитіла з інгібітором топоізомерази трастузумабу дерукстекану (T-DXd), який продемонстрував активність у дослідженні I фази DS-8201а та показав об’єктивну частоту відповіді 14/34 (41,2 \%) у пацієнток із низьким рівнем HER2 [2].

Повідомлено попередні результати II фази дослідження DAISY у пацієнток з поширеним РМ3 незалежно від HER2-статусу. Показник відповіді за умови HER2 0 \% (IГX) становив 30 \% (табл. 1) [3]. Зараз триває дослідження III фази для оцінювання ефективності та безпеки T-DXd у пацієнток із низьким рівнем HER2, які мають неоперабельний рак молочної залози (DESTINY-Breast04, NCT03734029) [4].

\section{II. Рак усереаині раку}

Можливості лікування HR+ та HER2/neuпозитивного раку М3 призвели до ефективного контролю хвороби та значного покращення загальної виживаності. Проте тричі негативний РМЗ традиційно характеризується несприятливим прогнозом та дефіцитом мішеней для таргетної терапії. Тільки 20 \% цих пухлин реагують на стандартні лінії хіміотерапії. Удосконалення лікування цього підтипу раку є пріоритетом сучасних досліджень, проте жодне з них не є перспективним у лікуванні всіх підтипів ТНРМЗ. Навіть цей невеликий клас пухлин можна розподілити на підкласи зі своїми власними молекулярними особливостями та чутливістю до терапевтичних засобів (рис. 2).

Згідно з літературою, виділяють 7 підтипів ТНРМ3: базальноподібний-1 і -2, імуномодулюючий, мезенхімальний, мезенхімальний стовбуроподібний, підтип із люмінальними андрогеновими рецепторами (LAR), клаудинподібний тип раку (claudin-like) [5]. Проте лише 4 з них розглядаються зараз як такі, що мають значення у клінічній практиці (рис. 2). Коротко розглянемо кожний з них.

\section{1. Аія на рецептори анАрогенів - потенційна мішень А^я таргетної терапії при ТНРМЗ}

Підтип LAR становить 10-15\% тричі негативних пухлин та характеризується низькими темпами проліферації та люмінальноподібним профілем експресії генів. До того ж цей підтип, як і люмінальний, характеризується нижчим відсотком повної відповіді (CR) $10 \%$ після неоад'ювантного лікування порівняно з базальноподібним - 51 \%. Клінічні дані свідчать, що, зважаючи на резистентність до хіміотерапії, експресія рецепторів андрогену не свідчить про гірший прогноз. LAR генетично та гістологічно схожий на естрогенпозитивний рак M3, отже, це відкриває нам можливості 
Таблиця 1. Попередні результати дослідження DAISY II фази

\begin{tabular}{|c|c|c|c|c|}
\hline Показник & Разом & $\begin{array}{c}\text { Когорта I } \\
\text { (пацієнтки з виявленою } \\
\text { ампліфікацією гена } \\
\text { HER2 або HER2 3+ } \\
\text { за IГX) }\end{array}$ & $\begin{array}{c}\text { Когорта II } \\
\text { (пацієнтки } \\
3 \text { пухлинами } \\
\text { HER2 2+ та 1+ } \\
\text { за IГX) }\end{array}$ & $\begin{array}{c}\text { Когорта III } \\
\text { (пацієнтки } \\
3 \text { пухлинами } \\
\text { HER2 - 0\%) }\end{array}$ \\
\hline $\begin{array}{l}\text { Найкращий середній рівень } \\
\text { відповіді - найкраща від- } \\
\text { повідь, зафріксована від по- } \\
\text { чатку лікування до прогре- } \\
\text { сування, кількість пацієнтів }\end{array}$ & $82 / 176(46,6 \%)$ & $47 / 68(69,1 \%)$ & 24/72 (33,3 \%) & $11 / 36(30,6 \%)$ \\
\hline $\begin{array}{l}\text { Середня тривалість відпо- } \\
\text { віді на лікування, місяці }\end{array}$ & 7,6 & 9,9 & 7,6 & 6,8 \\
\hline $\begin{array}{l}\text { Медіана виживаності без } \\
\text { прогресування, місяці }\end{array}$ & 6,9 & 11,1 & 6,7 & 4,2 \\
\hline
\end{tabular}

для схожих підходів у лікуванні, а саме до застосування антиандрогенної терапії [6].

Андрогеновий рецептор (АР) належить до родини стероїдних гормональних рецепторів, активується андрогенами - тестостероном або дигідротестостероном. Функціонує як лігандактивований інтрацелюлярний фактор транскрипції, який регулює експресію генів за допомогою взаємодії з ДНК. Незважаючи на певні відомості про роль АР у кількох сигнальних шляхах, їх роль у генезі пухлинного прогресування повністю не визначена. Збагачені АР клітини ТНРМЗ часто несуть мутації РІ3КСА, які роблять їх чутливими до інгібування PI3K/mTOR (дивись розділ PI3CA [6]).

У дослідженні II фази ENZA оцінювали ефективність ензалутаміду за умови АР+ субтипу. Первинною кінцевою точкою був показник клінічної користі через 16 тижнів (CBR), що є сумою випадків повної та часткової відповіді, а також випадків стабілізації захворювання (CR + PR + SD). Вторинні кінцеві точки включали виживання без прогресування (PFS) та профіль безпеки. Серед 118 пацієнтів, що отримували терапію,
78 мали експресію АР > 10 \%. Кінцеві точки були проаналізовані в обох групах: у пацієнтів, що були AP+, та в контрольній групі. CBR на 16-му тижні становив $33 \%$ у групі AP+ та 25 \% у контрольній групі. Було повідомлено про 2 випадки CR та 5 випадків PR. PFS становила 3,3 місяця у групі AP+ та 2,9 місяця у контрольній групі [7]. Результати цього дослідження стали основою для дослідження III фази ENDEAR у пацієнтів із поширеним ТНРМЗ без лікування або з 1 попередньою лінією терапії. Результати ще очікуються [8]. Для жінок із метастатичним AR+ THPM3 триває клінічне випробування III фази (NCT03055312), у якому порівнюють звичайну хіміотерапію з лікуванням бікалутамідом. У цьому дослідженні буде оцінено CBR через 16 тижнів, а також виживання без прогресування через 24 місяці.

Слід звернути увагу на відкрите випробування II фази, у якому було вивчено нестероїдний інгібітор АР - бікалутамід. Це було відкрите дослідження з однією групою, що включало пацієнтів з АР-позитивним (ІГХ > 10 \%) попередньо пролікованим метастатичним ТНРМЗ.

Позитивна експресія АР мала місце у 51 із 424 пацієнтів, що становило $12 \%$. Отримували лікування бікалутамідом 26 пацієнтів. Учасниці дослідження мали середній вік 66 років (діапазон 41-83), стан за ECOG 0-1, більшість мали вісцеральні метастази та отримували в середньому 1 попередню лінію хіміотерапії. Із 26 учасниць дослідження 5 пацієнток мали стабілізацію захворювання > 6 місяців, 2 пацієнтки $-<6$ місяців, а 19 - прогресування захворювання. У дослідженні не було досягнуто цільових показників ефективності експериментального лікування: показника клінічної користі (CBR) у $18 \%$ і медіани виживаності без прогресування захворювання (mPFS) 12 тижнів. 


\section{2. Терапевтична ро^ь $P I 3 K-A K T-m T O R$ у ^ікуванні тричі негативного раку молочної залози}

PI3K/AKT/mTOR - це сигнальний шлях, центральними компонентами якого $є$ ферменти фосфоінозитид-3-кіназа (PI3K), кіназа AKT та mTOR (mammalian target of rapamycin). У складі цих комплексів mTOR регулює клітинний ріст та проліферацію (рис. 3). Крім того, гіперактивація шляху PI3K, спричинена мутаціями PIK3CA та втратою PTEN, може сприяти резистентності до хіміотерапії.

Інгібування шляху PI3K - AKT - mTOR застосовується в онкогематології, у лікуванні нейроендокринних пухлин, раку нирки. Безумовно, одним із найвідоміших прикладів використання пухлинною клітиною цього сигнального шляху можна вважати HR-позитивний рак молочної залози. Проте порушення регуляції передачі сигналів через РI3К та сигнальний шлях AKT є другою за частотою онкогенною аберацією після мутації білка ТР53 при ТНРМЗ. Хоча мутації в певних генах трапляються порівняно рідко, комбіновані активуючі мутації в РІК3СА та AKT зустрічаються у 25-30 \% первинного ТНРМЗ. Найбільший відсоток мутації РІК3СА зустрічається при тих тричі негативних пухлинах, що попередньо вважалися люмінальними, проте 3 прогресуванням втратили експресію рецепторів та стали потрійно негативними [5].

У дослідженні SOLAR-1 порівнювали застосування комбінації алпелісиб + фулвестрант та плацебо + фулвестрант при поширеному HR+ раку молочної залози 3 мутацією РІК3СА (рис. 4). У групі алпелісиб + фулвестрант виживаність без прогресування становила 11 місяців порівняно з 5,7 місяця у групі плацебо + фулвестрант [9].
У дослідженні фази I/II, яке включало пацієнтів із ТНРМЗ, комбінація алпелісиб + набпаклітаксел продемонструвала активність у пацієнтів з HER2-негативним метастатичним раком. Показник об'єктивної відповіді пухлини становив $59 \%$, із них 7 - повна відповідь, $52 \%$ - часткова відповідь [10]. Триває подвійне сліпе плацебо-контрольоване дослідження III фази (349TiP EPIK-B3) алпелісибу з набпаклітакселом при поширеному тричі негативному раку молочної залози з мутацією РІКЗСА або PTEN і без мутації РІК3СА [11].

Інгібітори РІ3К на додаток до антагоніста АР були досліджені з метою посилення ефектів інгібіторної ендокринної терапії на АР, подібно до стратегії антиестрогенної терапії. Оскільки мутації РІКЗСА часто активуються в цих пухлинах, доклінічні дані показують, що АР-позитивні клітинні лінії ТНРМЗ є чутливими до інгібіторів PI3K/mTOR при застосуванні разом із бікалутамідом. Тривають клінічні випробування фази Ib, що оцінюють комбінацію інгібітору $\beta$-PІ3-кінази таселісибу в комбінації з палбоциклібом при метастатичному раку молочної залози та включають когорту ТНPM3 (PIPA trial, NCT02389842) [12]. Нещодавно було розпочато дослідження комбінації таселісибу (інгібітор PI3K $\alpha$ ) та ензалутаміду (NCT02457910) при AR+ i PTEN+ раку молочної залози, включно 3 когортою ТНРМЗ [13]. Інше клінічне випробування фази I поєднує $\alpha$-специфічний інгібітор РІ3К-кінази алпелісиб з ензалутамідом при AR+ i PTEN+ раку молочної залози, включно з когортою ТНРМ3 (NCT03207529) [14].

Результати цих досліджень внесуть ясність, як інгібування РІ3К-шляху впливає на віддалені результати лікування в пацієнтів із тричі негативним раком молочної залози.

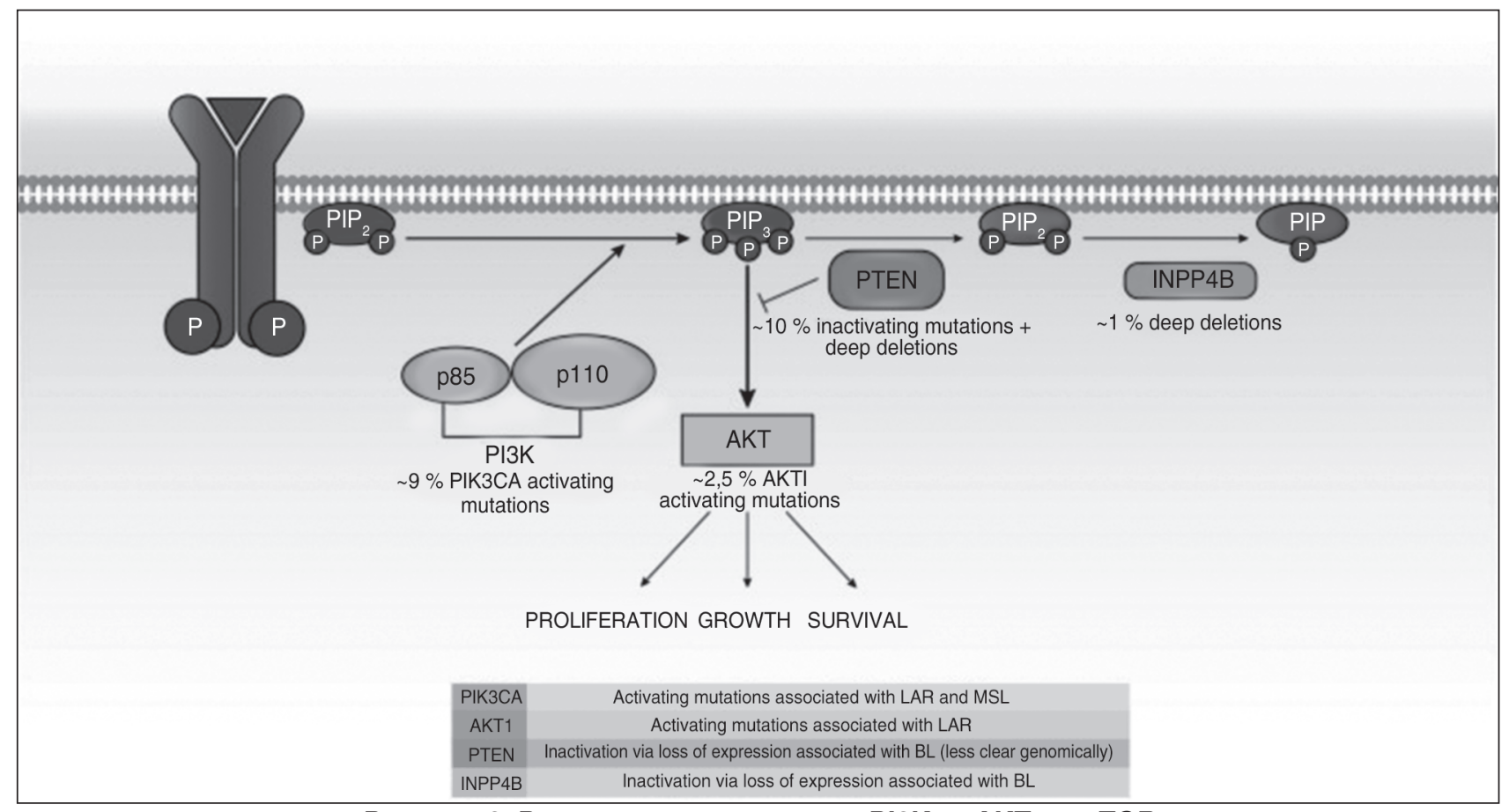

Рисунок 3. Роль сигнального шляху PIЗK - AKT - mTOR 


\section{3. Мутації в генах BRCA1, BRCA2 та інші причини АеФекту гомологічної рекомбінації як переАУмова А^я застосування принципу синтетичної летальності}

Дефекти гомологічної рекомбінації (ДГР) забезпечують високу мутагенність пухлини. За браком належної роботи системи репарації пошкодження в ДНК накопичуються, кількість мутацій у клітині зростає. Саме це $є$ одним із механізмів, що сприяють канцерогенезу в нормальній клітині, розвитку злоякісного новоутворення, селекції агресивних клонів у пухлині. Проте ці знання надають можливість застосувати фундаментальну властивість пухлини - геномну нестабільність проти неї самої.

Наявність ДГР забезпечує чутливість пухлинних клітин до препаратів, що забезпечують пошкодження ДНК, у тому числі до алкілуючих агентів (а особливо до препаратів платини) та до PARP-інгібіторів (інгібіторів полі-АДФ-рибози полімерази).

Білки BRCA1 і BRCA2 вважалися головними білками системи репарації, а мутації їхніх генів - єдиною причиною дефекту гомологічної рекомбінації. Проте зараз відомо, що гомологічна рекомбінація є системою з декількома молекулярними учасниками й порушення роботи будь-якого з них може призвести до ДГР. Наприклад, втрата клітиною одного з білків СНЕК2, WEE1, PALB2, RAD51 сприяє надбанню BRCAподібного фенотипу (визначеного як BRCAness) [15]. Ці білки утворюють комплекс, який разом із білками PARP виконує ексцизію порушеної ділянки ДНК, pe- комбінацію ДНК та побудову нових ланцюгів. Практикуючому лікарю не потрібно запам'ятовувати всі білки та їхнї функції, потрібно лише усвідомити, що, наприклад, спадковий рак молочної залози - це не тільки про BRCA: мутація будь-якого з цих генів призведе до ДГР та до виникнення злоякісної пухлинної клітини.

Хоча сьогодні спадкові мутації BRCA1/2 є єдиними біомаркерами чутливості до PARP-інгібіторів, що підтверджено в рандомізованих клінічних випробуваннях (EMBRACA [16], OlympiAD [17]), сучасні досягнення застосування PARP-інгібіторів відкривають нові перспективи для подальших досліджень. Неможливість рутинного застосування NGS-методу для дослідження мутацій в інших генах, що відповідають за ДГР, обмежує застосування PARP-інгібіторів для пухлин зі статусом BRCAness. Проте дослідження із застосуванням інгібіторів полі-АДФ-рибози полімерази для пухлин зі спільними молекулярними особливостями на основі концепції про синтетичну летальність тривають і обіцяють нам широкі перспективи.

\section{4. Як щоАО імунотерапії?}

Імунна система є важливою для супресії розвитку раку. Зараз відомо, що пацієнти з тричі негативним раком молочної залози мають передумови для отримання переваги від застосування імунотерапії через наявність мутацій (високий рівень мутаційного навантаження), мікросателітної нестабільності, неоантигенів пухлини, підвищеної експресії PD-L1, лімфоцитів, що ін-

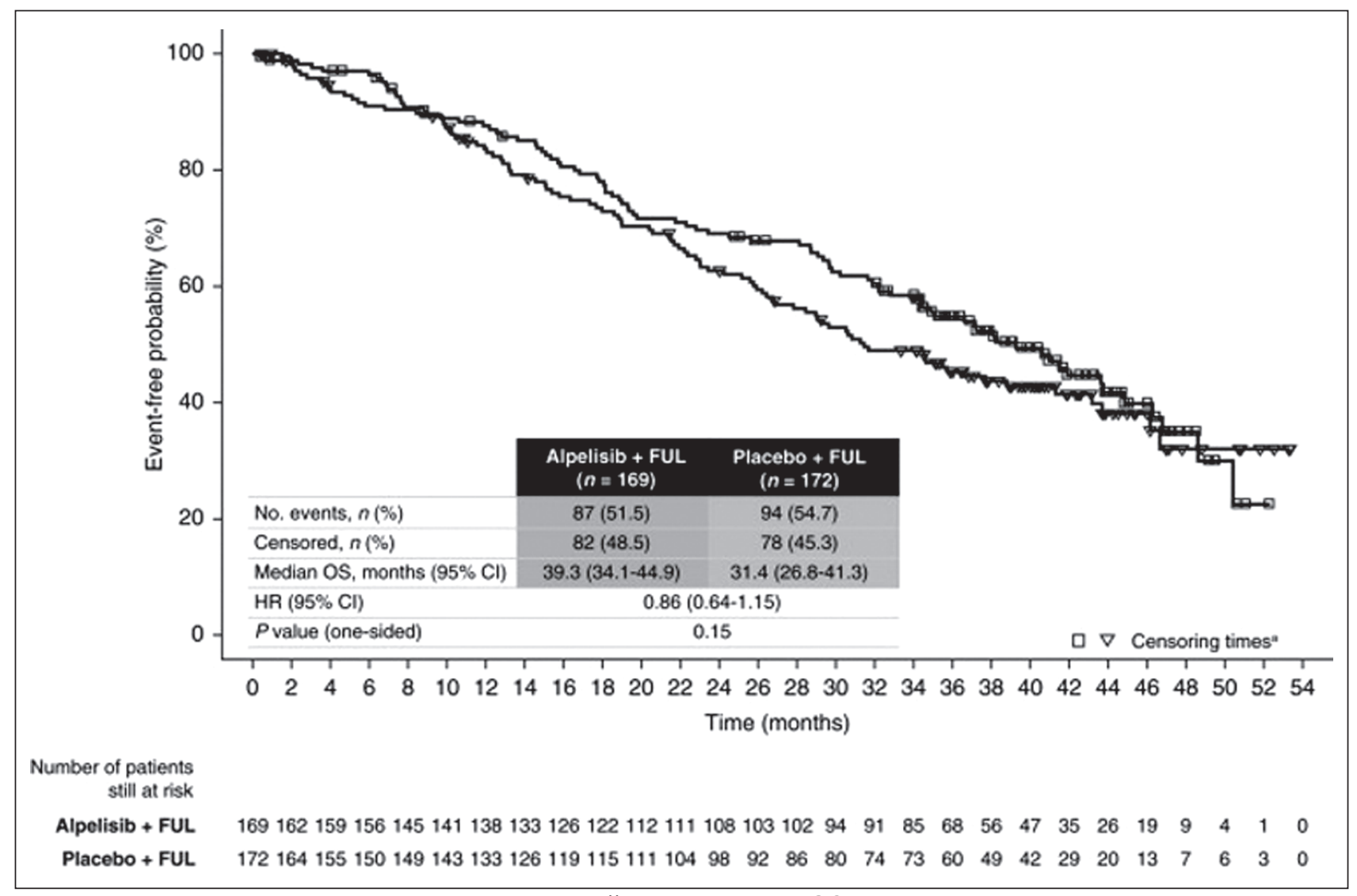

Рисунок 4. Дизайн дослідження SOLAR I [10] 


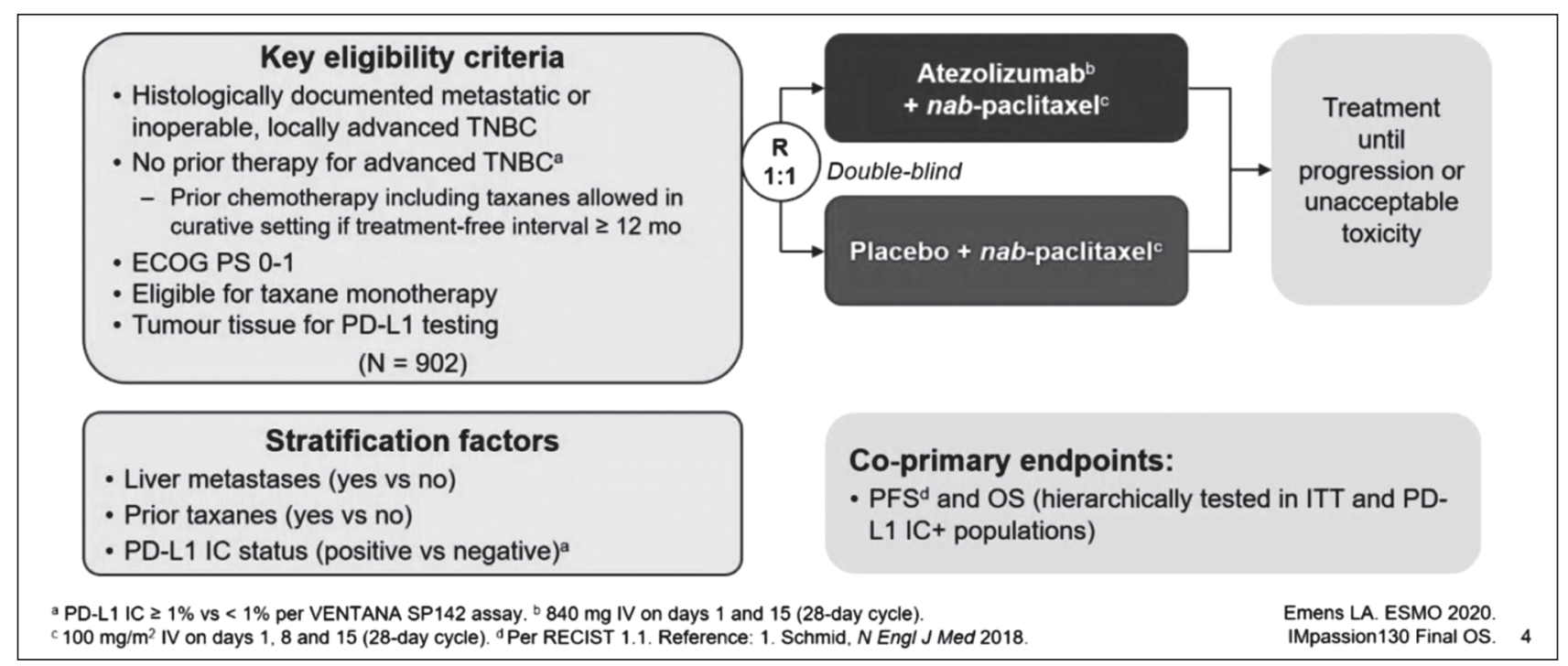

Рисунок 5. Дизайн рандомізованого дослідження IMpassion130

фільтрують пухлину (TIL). TIL почали розглядатися як інструмент для оцінювання імунної реактивності при різних злоякісних пухлинах, зокрема товстої кишки, яєчників, легень, сечового міхура, молочних залоз. Накопичені дані свідчать про те, що ступінь лімфоцитарної інфільтрації в пухлинній тканині має прогностичну цінність, зокрема, при тричі негативних пухлинах та пухлинах із гіперекспресією HER2 та є незалежним маркером сприятливого прогнозу. Крім того, інфільтруючі пухлину лімфоцити реалізують місцеву імунну відповідь, спрямовану проти росту пухлини та метастазування.

Хіміотерапія є основним методом лікування метастазуючого ТНРМЗ, але прогноз залишається невтішним, навіть після якісно проведеного лікування, через швидкий розвиток резистентності до препаратів. Отже, модуляція імунної системи є перспективною стратегією лікування таких пухлин. У 2018 р. ми були зосереджені на експресії PD-L1 при меланомі та раку легені. Але у червні 2020 р. були опубліковані дані дослідження IMpassion130 щодо користі застосування препарату атезолізумаб, що є інгібітором контрольних точок, з наб-паклітакселом при метастатичному тричі негативному раку молочної залози (рис. 5) [18].

Це подвійне сліпе плацебо-контрольоване клінічне випробування III фази, що включало 902 пацієнти. Вони були рандомізовані на дві групи: ті, що отримували режим атезолізумаб + наб-паклітаксел $(\mathrm{n}=451)$, та ті, що отримували плацебо + наб-паклітаксел $(\mathrm{n}=451)$. 41 \% пацієнтів в обох групах були PD-L1-позитивними. За результатами дослідників, 3-річна загальна виживаність зросла до 36 \% режимі атезолізумаб + набпаклітаксел із 22 \% у групі наб-паклітакселу з плацебо в когорті PD-L1-позитивних пацієнтів. На підставі цього дослідження FDA надало прискореного схвалення атезолізумабу в комбінації з наб-паклітакселом для лікування пацієнтів із неоперабельним місцевопоширеним або метастатичним PD-L1+ THPM3. Це перший інгібітор контрольної точки, схвалений для застосування при метастатичному РМЗ.

\section{Висновок}

3 практичної точки зору, РМЗ потрібно розглядати як збірну нозологічну форму, у яку включені підтипи пухлин, принципово різні за біологічними, генетичними, гістологічними та клінічними особливостями. Успіх у лікуванні хворих на рак молочної залози підкреслює важливість застосування персоніфікованого підходу та комплексного оцінювання пухлинних маркерів. На сьогодні клінічне значення (прогностичне і предиктивне) мають такі показники: статус рецепторів ER, PR, HER2, AP, мутація PI3CA, гени BRCA1/BRCA2 та експресія PD-L1 у пухлинних клітинах. Пошук нових мішеней та шляхів цілеспрямованого впливу на них з терапевтичною метою залишається актуальним питанням у лікуванні метастатичного раку молочної залози.

Конфлікт інтересів. Автор заявляє про відсутність конфлікту інтересів та власної фінансової зацікавленості при підготовці даної статті.

\section{Список мітератури}

1. Biopsy of liver metastasis for women with breast cancer: impact on survival. 2012 June [PubMed].

2. DS-8201a, A Novel HER2-Targeting ADC with a Novel DNA Topoisomerase I Inhibitor, Demonstrates a Promising Antitumor Efficacy with Differentiation from T-DM1. 2016 March [PubMed].

3. Study of DS-8201a, an Antibody Drug Conjugate for Advanced Breast Cancer Patients, With Biomarkers Analysis. 2021 March (DAISY).

4. Trastuzumab Deruxtecan (DS-8201a) Versus Investigator's Choice for HER2-low Breast Cancer That Has Spread or Cannot be Surgically Removed [DESTINY-Breast04].

5. Practical classification of triple-negative breast cancer: intratumoral heterogeneity, mechanisms of drug resistance, and novel therapies. 2020 October [Nature].

6. Androgen receptor in triple negative breast cancer: A potential target for the targetless subtype. July 2018 [ScienceDirect].

7. Results from a phase 2 study of enzalutamide (ENZA), an androgen receptor (AR) inhibitor, in advanced AR+ triple-negative 
breast cancer (TNBC). 2015 ASCO Annual Meeting I [Journal of clinical oncology].

8. Abstract OT3-02-02: ENDEAR: A randomized international phase 3 study comparing the efficacy and safety of enzalutamide in combination with paclitaxel ChT or as monotherapy vs placebo with paclitaxel in patients with advanced TNBC [Cancer Research].

9. Alpelisib for PIK3CA-Mutated, Hormone Receptor-Positive Advanced Breast Cancer. 2019 May [The new England journal of medicine].

10. Clinical and Biomarker Results from Phase I/II Study of PI3K Inhibitor Alpelisib plus Nab-paclitaxel in HER2-Negative Metastatic Breast Cancer. 2021 February [PubMed].

11. 349TiP EPIK-B3: A phase III, randomised, double-blind $(D B)$, placebo $(P B O)$-controlled study of alpelisib $(A L P)+n a b-p a-$ clitaxel (nab-PTX) in advanced triple-negative breast cancer (TNBC) [Annals of oncology].

12. PIPA: Combination of PI3 Kinase Inhibitors and PAlbociclib [ClinicalTrials].

13. Taselisib and Enzalutamide in Treating Patients With Androgen Receptor Positive Triple-Negative Metastatic Breast Cancer [Clinical Trials].
14. Alpelisib and Enzalutamide in Treating Patients With Androgen Receptor and PTEN Positive Metastatic Breast Cancer [Clinical Trials].

15. BRCAness revisited. 2016 February [PubMed].

16. Embraca trial Talazoparib in Patients with Advanced Breast Cancer and a Germline BRCA Mutation [The new England journal of medicine].

17. Olaparib for Metastatic Breast Cancer in Patients with a Germline BRCA Mutation. 2017 August [The new England journal of medicine].

18. Atezolizumab and Nab-Paclitaxel in Advanced Triple-Negative Breast Cancer [The new England journal of medicine].

19. Phase II trial of bicalutamide in patients with androgen receptor-positive, estrogen receptor-negative metastatic Breast Cancer. Aug 2013 [PubMed].

Отримано/Received 08.11.2021

Рецензовано/Revised 22.11.2021

Прийнято до друку/Accepted 30.11.2021

K.D. Hlovatska

Bogomolets National Medical University, Kyiv, Ukraine

Odesa Regional Oncological Center, Odesa, Ukraine

\section{Metastatic triple-negative breast cancer: a dead end or a permanent stimulus for scientific research in clinical oncology? (Scientific essay)}

Abstract. Breast cancer remains one of the most common malignant neoplasms in women in the world, both in developed and developing countries. According to Globocan data in 2020, the number of breast cancer cases is $11.7 \%$ of all cases of diagnosed cancer. In Ukraine, the highest incidence rate $(27.6 \%)$ and mortality (25.5\%) from breast cancer among women fall on the age of 30-54, that is, the most socially active period of life. Metastatic breast cancer is a term for a wide group of diseases with a common mechanism of occurrence but with a pronounced diversity in histology, biology, and clinical presentation. Modern treatment of hormone-positive cancers and HER2/neu positive subtypes results in long-term disease control and significant improvement in disease-free and overall survival rates. However, 10-15\% is a triple-negative subtype, traditionally characterized by aggressive behavior, poor prognosis, and a deficiency of targets for targeted therapy. Thus, the search for new targets that can be assessed and their practical application in the treatment of breast cancer remains an urgent issue.

Keywords: breast cancer; hormone-negative cancer; treatment 